\title{
Fenomena Dakwah Online dan Offline Ustadz Abdus Somad di Pondok Pesantren Al-Amien Prenduan Sumenep Madura
}

\author{
Muhammad Munir \\ Universitas Islam Negeri Sunan Ampel, Indonesia \\ muniralafasy39@gmail.com
}

\begin{abstract}
This research was conducted to find out how the phenomenon of online propaganda that occurred among pesantren and the Madurese community, welcomed the arrival of Ustadz Abdus Somad, in facing the challenges of social media today. By using a qualitative research approach. The results of this study indicate that the views of the santri community and alumni of Al-Amien Prenduan Islamic boarding school on the phenomenon of online propaganda are three, namely: challenge from offline media, challenges from online media, internet as media propaganda. (a) The challenge of Offline Media is the challenge in the form of the order at the venue, such as the sound system, the audience, the presence of the audience, (b) The challenge of online media is that organizers must be able to arrange for online media to be noticed also because this really helps the virtual community to be able to watch when they are unable to attend the place of the event (c) the Internet as a propaganda media, this is one of the advantages of the internet in the realm of da'wah that is able to search for content, videos, and new things.
\end{abstract}

Keywords: Phenomenon, Da'wah Online, Da'wah Offline

\begin{abstract}
Abstrak
Penelitian ini dilakukan untuk mengetahui bagaimana fenomena dakwah online yang terjadi dikalang pesantren dan masyarakat Madura, menyambut kedatangan ustadz Abdus Somad, dalam menghadapi tantangan media sosial saat ini. Dengan menggunakan pendekatan penelitian kualitatif. Hasil penelitian ini menunjukan bahwa pandangan masyarakat santri dan alumni pondok pesantren Al-Amien Prenduan pada fenomena dakwah online ada tiga yaitu: tantang dari media offline, tantangan dari media online, internet sebagai media dakwah. (a) Tantangan dari Media Offline adalah tantang yang berupa seperti tatanan yang ada pada tempat berlangsungnya acara, seperti sound sistem, pangggung, kehadiran audience, (b) Tantangan dari media online hal ini para penyelenggaran harus bisa memanaj agar media yang berupa online agar diperhatikan juga karena hal ini sangat membantu masyarakat virtual agar bisa menyaksikan dikala belum bisa hadir ketempat acara (c) Internet sebagai media dakwah, ini salah satu keunggulan internet ada pada ranah dakwah yaitu bisa mencari konten, video, dan hal-hal yang baru.
\end{abstract}

Kata Kunci: Fenomen, Dakwah Online, Dakwah Offline 


\section{Pendahuluan}

Ketenteraman dalam kehidupan masyarakat merupakan salah satu harapan seluruh masyarakat didunia, tidak juga masyarakat yang di Indonesia khususnya yang sedang memiliki pola kedihapun dan dinamika kehidupan yang sangat tinggi. Hal ini merupakan keharusan dalam dunia globalisasi yang memberikan sebab dna akibat kepada besarnya perjalanan informasi yang masuk ke dalam asepek dan pola kehidupan sehingga membeuk perilaku yang hidup dengan berasakan pancasila. Perubahan positif misalnaya, dan perubahan negatif pun belum dapat dijadikan sebagai arus informasi yang dapat mengkontrol. Oleh karena itu, diperlu adanya usaha penangaanan dalam permasalahan moral bagi generasi melenial khususnya supaya suatu kondisi mereka sesuai dengan norma yang Allah berikan. Salah satu cara supaya dapat dilakukan adalah melalui pesuasi dari bidang dakwah. (Syekh Ali Mahfudz, 1975:23)

Perkembangan teknologi mendorong perkembangan media massa sebagai sarana komunikasi. Perkembangan media sosial, massa, baik cetak dari bidang elektronik, menjadikan informasi dan hiburan yang berkembang pesat di tengah masyarakat. Aneka informasi disuguhkan oleh media. Aneka program hiburan ditawarkan di media massa elektronik dan cetak, tidak terkecuali informasi yang berkaitan dengan aspek-aspek keagamaan yang ditayangkan oleh media. (Melvin L De Fleur and Rokeach, 1982:132)

Munculnya banyak media, terutama media sosial seperti televisi, youtube, Instagram, Facebook, Whatsup, pada akhirnya menuntut media untuk menayangkan berbagai konten yang mereka punya, apalagi pada baru-baru ini sedang gentar-gentarnya politik di Indonesia akan tetapi pembahasan kali ini tidak mengarah kepada politik. Maka konten-konten media islam seharusnya menyiarkan dengan kemasan yang sesuai dengan momen yang pas dan khalayak yang menjadi sasarannya. Tetapi 
dakwah yang dikemas pada saat ini terutama di era industri media yang pada dasarnya tayangan media tersebut tidak dapat dilepaskan dari kepentingan industri yang bernama kapitalisme. (Melvin L De Fleur and Rokeach, 1982:132)

Kegiatan dakwah Islam di Indonesia seperti mengalami evolusi dalam ruang massa, salah satunya ialah dakwah dijadikan sebagai penawaran ajakan dalam spiritual yang muncul dengan berbagai bentuk yang sangat banyak. Hal yang berbeda itu bisa beraktivitas dalam dakwah yang papat mendorong kuat elemen lain yang tidak ada dalam ruang lingkup dakwah itu sendiri. Dalam ilmu dakwah, media adalah hal yang cenderung dimengerti sebagai (channel) yang diperagakan oleh para Da'i baik personal maupun general untuk menyampaikan pesan dakwah itu sendiri. (Asmuni Syukir, 1983:65)

Kondisi masyarakat pada saat ini, yang tidak bisa kita pungkiri lagi notabene mereka yang telah menjadi bagian masyarakat secara global, aktivitas dan kegiatan dakwah inilah dapat ditemui di kelaskelas dan media-media di dunia maya. Misalnya hari ini, masyarakat dapat mengakses informasi religius dari smartphone kita, terlebih jika masyarakat tersebut mempunyai jalur ke dunia sosial atau publik. Fenomena ini sebanarnya telah lama terjadi, ketika semua masyarakat mulai menggunakan media sosial dakwah islam itu seakan menjadi hal dalam media alternatif. Kemunculan media online dalam Islam ini tentu mempunyai nuansa dakwah. Bahkan, beberapa tahun ini, muncul pula fenomena facebook yang akan "diharamkan” oleh sebuah lembaga komunitas muslim di Surabaya karena mereka merasa diresahkan. Selain semua itu, fenomena ini memperlihatkan daya tarik media untuk membuka ruang seluas-luasnya bagi siapapun untuk melakukan kegiatan dakwah Islam. (Nurudin, 2003:78)

Dalam fenomena in bahwa masyarakat global kita yang saat ini salah satunya sebagai orang yang dapat dengan tingkat akses informasi 
yang tinggi salah satunya adalah dakwah sesungguhnya mereka sedang dilema. Masalah yang pertama, dakwah Islam mempunyai kepentingan yang besar diatas media-media saat ini. Masalah yang kedua, eksistensi dakwah secara merakyat sedang dihadapkan dengan ancaman lantaran adanya media. Di sisi lain, dakwah berpikir bahwa kemunculan media sebagai sarana dan saluran yang berinovasi berharga dan dapat memberikan membantu perkembangan dakwah. tetapi, pada disaat yang bersamaan, dakwah juga berhadapan dengan hegemoni media yang dilakukan untuk invasi atau penjajahan atas dakwah Islam. (Mahmudin, 1983:87)

Dalam fenomena pasar industri islam juga manfaatkan media dan teknologi sebagai alat komunikasi dan informasi dalam dunia masyarakat publik telah menjadi tren, dan mempunyai rating dalam kehidupan sosial dan budaya. feedbacknya, masyarakt yang tidak dapat beradaptasi dengan kecanggihan teknologi dianggap sebagai masyarakat tradisional, kurang saluran media, dan kuno. manfaat teknologi dan juga media sosial sudah menjadi tanda pasar industri, yang memberikan hegemoni dalam kehidupan masyarakat kita. Terlebih dengan adanya perkembangan industri media, terutama televisi, youtube, facebook, whatsup, dll, pada zaman sekarang ini, yang telah menjadikan perubahan sosial dalam budaya masyarakat. Datangnya media sosial di sini, kedalam pola kehidupan masyarakat, dan semua itu mengubah pola pikir dalam aktivitas dalam kesehariannya. Hal ini, media sosial berarti memberikan peran yang berarti bagi masyarakat, salah satu contoh yang dilihat data yaitu dalam menonton dengan menggunakan konten-konten yang ada di dalam media sosial. Bahkan, tidak jarang orang dalam menggunakan media sosial bahkan per menit pun ada, sepertinya menjadi kewajiban, sehingga mengalahkan ibadah mereka yang merupakan salah satu kewajiban bagi mereka. Hidup berasa tidak berarti apabilah dalam satu menit saja tidak menggunakan media sosial atau media lainnya. (Baiquni, 1983:87) 
Dalam studi perspektif cultural studies industri media, khususnya televisi sering kali berkaitan dengan perkembangan masyarakat publik dan informasi. Dalam persektif masyarakat seperti ini, media khususnya televisi memiliki peran yang kuat yang dapat mengubah pola kehidupan masyarakat. Media adalah jalan suksesnya komunikasi dari berbagai subjek. Komunikasi adalah media atau jalan yang menjembatani komunikasi kepada seluruh masyarakat publik. Jadi, media dalam hal ini merupakan komponen komunikasi yang sangat berarti dalam masyarakat publik. (Didin Hafidhuddin, 2006:11)

Salah satu layanan dakwah online di Indonesia misalnya. Adanya program Dakwah online ini karena dunia internet memang "keren" alasannya karena penyeberan yang cepat dan juga luas. Dalam dakwah ini menyediakan berbagai konten di dalam layanannya, mulai dari teks, video, hingga audio. Dengan adanya internet disini, kenapa para khalayak memilih internet sebagai basis di awal untuk melihat kemudahan dan kecepatan. Analogi mendasar mungkin kalau kita bermain dengan satelit langsung mungkin terlalu mahal dan sulit untuk kita realisasikan, sedangkan dalam televisi biayanya terlalu mahal akan tetapi hal semua itu bisa kita selesaikan dengan uang, jadi kalau dua hal itu sudah ada pada para penda'i maka sangat mudah untuk melakukan live streaming serta menyimpan layanan video on-demand sendiri tanpa terkait ke YouTube, bahkan media sosial lainnya. (Moh Ali Aziz, 2004:156)

Tren anak zaman now adalah dakwah secara online atau hal yang online, setiap harinya selalu saja ada update kata dari bahasa kita itu tidak terlepas bahwa media sosal atau media yang online saat ini telah ada pada kehidupan masyarakat bahkan anak muda generasi melenial, dari banyak manfaat yang bisa amati saat ini adalah hadirnya sebuah teknologi mobile yang canggih. Mereka lebih menyukai potongan Videovideo dalam teks yang berbinspiratif tentang islam ini justru lebih mereka download dan di tonton, yang tidak sedikit beredar di media 
sosial yang ada dalam smartphone mereka. Salah satu hal yang membuat dakwah (secara langsung) konvensional alias face to face berkurang. Kemungkinan konten yang mereka sajikan sudah sering disampaikan oleh pera penda'i melalui media streaming melalui Facebook, Instagram dan youtube, dan lain-lain. (Iskandar, 2009:44)

Setiap sesuatu pasti memiliki kelemahan, kelemahan pada dakwah online di mana tidak adanya kedekatan antara penceramah dan pendengar, dan menghilangkan kharomah seorang kiai ataupun ustadz, dakwah tatap muka lebih efektif dalam segi ikatan batin yang kuat. Orang-orang yang datang ke majelis punya ikatan batin yang kuat itu yang membedakan dengan dakwah secara online. Mereka sudah ada niat untuk datang ke majelis untuk mendengarkan ceramah atau sense untuk menerima ilmu sudah terbuka dengan adanya niat. Orang-orang bisa bersinergi dengan pendakwah, yang ceramah pun bisa lihat apakah materinya bisa diterima atau tidak dari gerak-gerik mereka, sebagai salah satu contoh pada penyampaian materi pendakwah memberikan materi yang susah maka audiensnya diam saja karena mungkin sulit menerima materi itu. (Kieron O Hara, 2002: 48)

Masalah inilah yang sudah terjadi pada generasi melenial kita, yang selalu menginginkan hal yang mudah dan tidak merugikan dirinya sendiri, mereka datang ke acara pengajian kebanyakan dari mereka terkadang tidak terlalu serius dalam mendengarkannya, sesekali ketika kejenuhan itulah mereka sempatkan buka handphone dengan alasan karena merasa isi ceramah yang disampaikan kurang menarik. Generasi millenial seperti sekarang, dengan datang media justru memudahkan para pengguna media dengan hal itu timbullah rasa enggan untuk hadir ke acara tersebut. "Mending, nonton online saja dari pada hadir ketempat lebih efesian jelas dan ekonomis, hal inilah yang membuat dakwah secara langsung terkikis dan banyak orang lebih memilih dakwah online." 


\section{Permasalahan}

Fokus permasalahan dalam penelitian ini adalah (1) bagaimana fenomena yang terjadi dikalang pesantren dan masyarakat Madura, menyambut kedatangan ustadz Abdus Somad, dalam menghadapi tantangan media sosial saat ini?

\section{Teori Jarum Hipodermik}

Hypodermic Needle Theory (Teori Jarum Hipodermik) Teori Peluru ini merupakan konsep awal efek komunikasi massa yang oleh para pakar komunikasi tahun 1970-an dinamakan pula hypodermic needle theory (teori jarum hipodermik).

Teori ini disamping mempunyai pengaruh yang sangat kuat juga mengasumsikan bahwa para pengelola media dianggap sebagai orang yang lebih pintar dibanding audience. Akibatnya, audience bisa dikelabui sedemikan rupa dari apa yang disiarkannya. Berbagai perilaku yang diperlihatkan youtube, whataspp, instagram, dan televisi dalam adegan filmnya memberi rangsangan kepada masyarakat untuk menirunya. Padahal semua orang tahu bahwa yang disajikan itu semua bukan yang terjadi sebenarnya. Akan tetapi, karena begitu kuatnya pengaruh televisi dan youtube penonton tidak kuasa untuk melepaskan diri dari keterpengaruhan itu. Maksud teori dalam penelitan ini ialah bagaimana masyarakat publik bisa jatuh pada perangkat media yang mereka gunakan setiap harinya dan bagaimana mereka memilah berbagai media yang banyak. (Onong Uchjana Effendi, 2003:83)

Teori Uses and Gratification (Teori Kegunanan dan Kepuasan) Teori uses and gratification ini merupakan penikmat media mempunyai kebebasan untuk memutuskan bagaimana (lewat media mana) mereka menggunakan media dan bagaimana media itu akan berdampak pada dirinya. Teori ini juga menyatakan bahwa media khususnya di youtube 
dan televisi dapat mempunyai pengaruh jahat dalam kehidupan. Penonton bersifat aktif yakni dapat memilih tayangan mana yang ingin mereka nikmati sesuai dengan kebutuhan mereka untuk mendapatkan kepuasan. Dalam teori ini juga masyarakat dan alumni dari pondok tersebut bisa memilih untuk hadir ke tempat acara secara langsung dan juga bisa melakukan nonton online di youtube. Kegunanaan teori dalam penelitian ini ialah bagaimana masyarakat publik bisa memilih apa konten dan situs mana yang akan mereka nikmati dan mereka produksi. (Nurudin, 2007:34)

\section{Metode Penelitian}

Dalam membahas masalah Fenomena dakwah online ini maka peneliti menggunakan jenis penelitian deskriptif kualitatif dan pendekatannya Studi Kasus, dengan menggunakan metode pengumpulan data wawancara, observasi dan dokumentasi dengan banyak responden yang sudah menonton online dan yang sudah hadir di tempat sebanyak 50 orang, yang meliputi santri Al-Amien Prenduan dan para alumni dari pondok tersebut, serta para asatidz yang termasuk dalam pengawasan santri tersebut seperti kepala sekolah dan wakilnya.

Adapun lokasi penelitian ini bertempat di Pondok Pesantren AlAmien Prenduan Sumenep Madura Jawa Timur. Dengan pertimbangan bahwa dalam pesantren tersebut telah mendatangkan ustadz Abdus Somad dan pertama kali ke pulau Madura. Sedangkan dalam analisis data peneliti menggunakan reduksi data, sintesisasi, menyusun hipotesis kerja. Dalam pengecekan keabsahan data peneliti menggunakan triangulasi dan perpanjangan keikutsertaan.

\section{Dakwah Online dan Offline dalam Dakwah Ustadz Abdus Somad di Pondok Pesantren Al-Amien Prenduan Sumenep Madura}

Dalam kedatangan di pengajian pada tanggal 17 Maret 2019, ustadz Abdus Somad di sambut meriah oleh masyarakat madura walau- 
pun bertempat di Pondok pesantren Al-Amien Prenduan, akan tetapi pengajian ini kurang lebih 40 ribu masyarakat berserta santrinya di pondok Al-Amien Prenduan. Dalam ceramah ustadz Abdus Somad didukung dengan adanya media offline seperti yang di jelaskan pada kajian teori istilah ini sebutan saat kita tidak terhubung dengan internet, lebih tepatnya tidak terkoneksi seperti: pengeras suara. Kelebihan media offline ialah bisa langsung bertemu dengan penceramah, dan juga kedekatan dakwah tatap muka lebih efektif dalam segi ikatan batin yang kuat. Orang-orang yang datang ke majelis punya ikatan batin yang kuat.

Disamping penggunaan media offline ustadz Abdus Somad juga di bantu dengan media online yang disediakan oleh panitia penyelenggara, dengan live streaming di youtube. Kelebihan media online ini juga sangat bermanfaat bagi masyarakat, Alumni pondok pesantren itu sendiri yang jauh dari pondok pesantren Al-Amien Prenduan, barangkali alasan tidak hadir secara langsung di pondok pesantren Al-Amien Prenduan, diterpa oleh berbagai aspek, salah satunya aspek ekonomi, kurangnya biaya transport untuk pergi ke acara tersebut. Dengan adanya media online masyarakat terbantu untuk tidak mengeluarkan biaya banyak dengan menonton live streaming tersebut, dibandingkan biaya hadir ke tempat acara dibandingkan beli paketan atau wifi.

Hambatan-hambatan dakwah secara tatap muka sangatlah banyak, salah satu contohnya seperti gangguan teman duduk, sehingga membuat pendengar tidak fokus untuk mendengarkan ceramahnya. Hambatan yang lain bisa dari sound yang kurang keras, terjadinya hujan di tempat acara karena waktu pelaksaan acara tersebut kebetulah hujan. Hal inilah yang membuat orang memilih untuk melihat kembali bagi yang sudah hadir karena kelebihan dakwah online ini ialah bisa di reaply jika suatu saat kita membutuhkan.

Keburukan dakwah online ini juga sangat banyak, salah satunya ialah kurang tatakrama kepada penceramah. Contohnya nonton sambil 
tiduran, nonton sambil minum kopi di warkop, nonton sambil pacaran mungkin, hal inilah yang menyebabkan kurangnya ikantan batin dengan penceramah. Solusi untuk media online ini, sampai saat ini penulis belum bisa memberikan solusi yang sangat konkrit akan tetapi adanya dakwah online ini ialah dengan adanya orang ketiga untuk menyampaikan pesan para penceramah.

Respon masyarakat pun berbeda-beda dalam menilai isi materi yang disampaikan oleh ustadz Abdus Somad. Untuk menjawab permasalahan diatas maka kami paparkan temuan penelitian.

\section{Fenomena di Kalangan Pesantren dan Masyarakat Madura Atas Kedatangan Ustadz Abdus Somad secara Offline}

Sebelumnya kita pernah membahas bahwa media ialah sarana yang dijadikan sebuah alat untuk memberikan pesan dari komunikator kepada kepada komunikan bahkan masyarakat publik. dapat kita ketahui bersama bahwa media adalah setiap sesuatu yang mempunyai alat komunikasi, baik cetak, maupun audio visual, yang bisa digunakan untuk memberikan informasi dari komunikator ke komunikan sehingga mendapatkan suatu bertindak. Sedangkan offline adalah berasal dari dua kata yaitu off yang artinya mati dan line yang artinya saluran, yang dimaksud dengan kata offline adalah keadaan yang tidak terhubung atau terkoneksi internet ke suatu jaringan atau saluran internet. Offline adalah sebutan saat kita tidak terhubung dengan media internet, lebih tepatnya terputus atau tidak terkoneksi. Sehingga media offline adalah media tidak terhubung dengan internet, lebih tepatnya tidak terkoneksi dengan jaringan internet. (Deddy Mulyana, 2001:56)

Maksud dalam penelitian ini ialah sistematika pengaturan dalam acara baik dari sistem elektronik, sistema ke panitian, sistem penataan panggung, dan lain-lain yang belum disebutkan. Tantangannya adalah bagaimana kita mengkemas hal yang terjadi di tempat sesuai dengan 
kemauan para undangan dan para khalayak yang hadir, karena khalayak pada saat itu yang hadir bukan hanya para santri dan alumni melaikan para masyarakat yang ada di sekitar lingkungan pesantren bahkan seluruh Madura.

\section{Fenomena di Kalangan Pesantren dan Masyarakat Madura Atas Kedatangan Ustadz Abdus Somad secara Online}

Perkembangan media yang pesat khusus pengguna internet atau media online yang tumbuh sangat pesat tahun 1990-an yang berupa jaringan internet. Program inilah yang disebut www, atau Worl Wide Web, berjalannya perkembangan komunikasi juga semakin berkembang, maka kebutuhan informasi yang sangat meningkat. Menjadikan pengguna media menjadikan sarana sebagai penyampaian informasi kepada masyarakat publik banyak alat yang dapat digunakan pengguna media untuk menyampaikan pesan, meneruskan pesan atau menyebarkan pesan, hal ini bisa kita rasakan dari banyaknya media terutama media online yang berbasis saluran informasi yang berupa internet atau juga sistem yang ikut serta dalam perkembangan komunikasi. Sedangkan media online adalah sebuah organisasi yeng bertugas mempubikkan informasi yang berupa pesan sehingga bisa mempengaruhi berbentuk virtual. (Ghani Zulkiple, 2004:22)

Sebagai seorang alumni yang sangat berbakti kepada pondoknya mereka walaupun tidak hadir keacara yang di selenggarakan di pondok pesantren Al-Amien Prenduan. Maka hal inilah yang menjadikan kemenangan media dalam gelutan dakwah Islam.

Dakwah adalah sebuah kesuksan seorang Da'i yang dialakukan secara efektif dan efisien bahwakan sebelum melalukan ceramah mereka para da'i harus mengidentifikasi masalah terlebih dahulu untuk mengetahui masalah-masalah yang pernah muncul dan bakal muncul dan dilengkapi dengan pengenalan objek secara tepat. Sehingga 
para da'i tahun karakter para khalayaknya. Untuk menyampaikan dan memberikan pesan dakwah bagus, kepada seorang juru dakwah (da'i) dengan menggunakan beranekan ragam media dakwah, baik itu media modern (media elektronika) maupun media tradisional. (Mahmudin, 2004:7)

Hal demikian akan bisa mempermudah bagi juru dakwah untuk menyampaikan dakwah dan juga agar mudah dipahami oleh sasaran dakwah (mad'u), maka sebaiknya dakwah dilakukan dengan menggunakan salah satu media yang ada. Hal ini untuk menyesuaikan keadaan masyarakat yang tidak sama, di satu sisi sudah modern, di sisi lain masih tradisional. (Moh Ali Aziz, 2004:156)

Dengan adanya internet yang merupakan bagian media yang tepat untuk dijadikan sarana dalam berdakwah secara online. Hal itu dikarenakan pada saat ini internet sudah menjadi media dan sumber informasi yang canggih. Karena teknologi ini menampilkan berbagai kemudahan, kecepatan, ketepatan akses dan kemampuan menyediakan berbagai kebutuhan informasi setiap orang, kapan saja, dimana saja dan pada tingkat apa saja. Berbagai informasi yang dapat diperoleh melalui Internet antara lain lapangan pekerjaan, olahraga, seni, belanja, perjalanan, kesehatan, permainan, berita, komunikasi lewat email, mailing list, dan chatting, bahkan artikel-artikel ilmiah dalam berbagai disiplin ilmu, dan lain sebagainya. Hampir semua bidang tugas manusia, apapun jenisnya, dapat dicari melalui Internet. Internet sebagai sumber informasi memungkinkan semua orang untuk terus belajar seumur hidup, kapan dan dimanapun serta untuk keperluan apapun. Dan untuk kebutuhan belajar bagi setiap individu, Internet tidak hanya menyediakan fasilitas penelusuran informasi tetapi juga komunikasi. (Iskandar, 2009:43) 


\section{Simpulan}

Dari beberapa data penelitian yang penulis paparkan pada bab-bab sebelumnya dapat diberikan simpulan bahwa: (1) Bagaimana fenomena yang terjadi dikalang pesantren dan masyarakat Madura, menyambut kedatangan ustadz Abdus Somad, dalam menghadapi tantangan media sosial saat ini. (a) Tantangan dari Media Offline adalah tantang yang berupa seperti tatanan yang ada pada tempat berlangsungnya acara, seperti sound sistem, pangggung, kehadiran audience, dan masalah yang akan terjadi saat acara berlangsung. (b) Tantangan dari media online hal ini para penyelenggaran harus bisa memanaj agar media yang berupa online agar diperhatikan juga karena hal ini sangat membantu masyarakat virtual agar bisa menyaksikan dikala belum bisa hadir ketempat acara, bahkan bisa putar kembali walaupun sudah hadir ketempat acara inilah kelebihan media online dan tantang yang paling besar bisa dari internernya. (c) Internet sebagai media dakwah, ini salah satu keunggulan internet ada pada ranah dakwah yaitu bisa mencari konten, vidio, dan hal-hal yang baru. Jadi internet adalah media yang sangat membantu memajukan dakwah Islam.

\section{Daftar Pustaka}

Abraham, A. 2010, Dampak NegatifJejaring Media, PT. Java Pustaka Media Utama, Surabaya.

Astrid S. Susanto, 1982, Komunikasi Massa 3, Bina Cipta, Jakarta Aziz, Moh Ali, 2004, Ilmu Dakwah, Prenada Media, Jakarta.

Baiquni; A, 1983, Islam dan Ilmu Pengetahuan Modern, Pustaka, Jakarta. Bakhtiar; Amsar, 1997. Filsafat Agama, Logos, Jakarta.

Baroroh, Umul dkk. 2009. Efek Berdakwah Melalui Media Tradisional, IAIN Walisongo, Semarang. 
Effendi. Onong Uchjana, 2007. Komunikasi Teori dan Praktek, Remaja Rosda Karya, Jakarta.

Hafidhuddin, Didin. 2006. Media Massa Dakwah, Jakarta.

Hara, Kieron 0. 2002. Plato dan Internet, Terj. Johan Dwi B.S., Jendela, Yogyakarta.

Iskandar, 2009. Panduan Lengkap Internet, Penerbit Andi Offset, Yogyakarta.

Mahmudin, 2004. Manajemen Dakwah Rosulullah, Restu Ilahi, Jakarta.

Mahfudz, Syekh Ali. 1975. Hidayat al Mursyidin, Dar al-Mishr, cet. Ketujuh, Mesir.

Mulyana, Deddy. 2001. Ilmu Komunikasi: Suatu Pengantar. Rosdakarya. Bandung.

Munzir, Saputra, Metode Dakwah, Edisi Pertama, (Jakarta: Kencana. Cet. I. 2003

Nurudin, 2003, Komunikasi Massa, Cespur, Malang.

Syukir, Asmuni, 1983 Dasar-Dasar Strategi Dakwah Islam, Al-Ikhlas, Surabaya.

Zulkiple Abd. Ghani; 2004. Islam, Komunikasi dan Tekhnologi Maklumat, Jakarta.

Onong Uchjana Effendi. 2003, Ilmu Teori dan Filsafat Komunikasi. (Bandung: PT. Citra Aditya Bakti,)

Nurudin. 2007, Pengatar Komunikasi Massa. (Jakarta: PT. Raja Grafindo Persada) 